\title{
The Distribution of Goat Gastrointestinal Tractus Worm Egg at Rambon District of Nganjuk Regency
}

\author{
Sebaran Telur Cacing Saluran Pencernaan Kambing di Kecamatan Rambon \\ Kabupaten Nganjuk \\ ${ }^{1)}$ Arum Puspitasari, ${ }^{2)}$ Boedi Setiawan, ${ }^{3)}$ Setiawan Koesdarto, ${ }^{3)}$ Kusnoto, ${ }^{4)}$ Soeharsono, ${ }^{3)}$ Poedji \\ Hastutiek \\ ${ }^{1}$ Student, Faculty of Veterinary Medicine, Universitas Airlangga \\ ${ }^{2)}$ Department of Veterinary Clinic, Faculty of Veterinary Medicine, Universitas Airlangga \\ ${ }^{3}$ Department of Veterinary Parasitology, Faculty of Veterinary Medicine, Universitas Airlangga \\ 4)Department of Veterinary Anatomy, Faculty of Veterinary Medicine, Universitas Airlangga \\ Received: 04-08-2019, Accepted: 11-08-2019, Published Online: 16-08-2019
}

\begin{abstract}
This study aims to determine the distribution of worm tract infection in foat digestion in Sub-district of Prambon, Nganjuk Regency. This research was conducted in Agustus 2018Januari 2019 with 108 samples of stool examination iin laboratory of Helmintologi Airlangga University Department of Parasitology, were examinated by native, sedimentation. Floatation techniques, and distribution of worm types of feces. The results showed that 66 samples were positive infected by gastrointestinal worm, its indicated that helminthiasis was $61,11 \%$. On examination it was found some kind of worm eggs, which are: Oesophagustomum spp., Bunostomum spp., Haemonchus spp., Trichostrongylus spp., Strongyloides spp., Trichuris spp., Chabertia spp and Moniezia benedini. The results of study showed the most of worm distribution in feces is Haemonchus spp.
\end{abstract}

\section{Keywords : distribution, gastrointestinal tract, worm eggs, and season}

\section{Pendahuluan}

Kambing merupakan ternak yang mudah terinfeksi oleh cacing saluran pencernaan baik secara klinis maupun subklinis di negara berkembang (Zeryehun, 2012). Populasi ternak di Kabupaten Nganjuk tahun 2016 terdapat kambing 122.768 dan Domba 62.751 ekor (Dinas Peternakan Jawa Timur).

Kecamatan Prambon secara geografis sebagian besar wilayahnya dikelilingi oleh sungai dari aliran sungai Brantas, yang merupakan dataran rendah dan sering meluap ketika musim hujan. Air merupakan media perkembangbiakan yang baik bagi cacing saluran pencernaan dan media transportasi telur cacing. Wilayah Kecamatan Prambon memiliki struktur tanah yang cukup produktif untuk berbagai jenis tanaman (Badan Pusat Stastika Kabupaten Nganjuk, 2016). Air sangat mendukung perkembangbiakan cacing pada kambing yang cenderung menyukai tanah yang subur (Ilham, 2014). Penyebaran infeksi cacing terjadi cukup tinggi pada daerah tropis yang lembab dan panas, sehingga mendukung kelangsungan hidup cacing tersebut (Yulianto, 2007).
Keberadaan parasit saluran pencernaan pada suatu daerah tertentu sangat tergantung pada curah hujan, kelembapan dan temparatur yang bervariasi di setiap daerah. Keadaan iklim yang lembab merupakan keadaan yang paling baik untuk fase hidup dari berbagai parasit saluran pencernaan (Beriajaya dan Stevenson, 1985). Di beberapa desa di kecamatan Prambon memiliki curah hujan rata-rata $210 \mathrm{~mm}$ pertahun dan suhu $\pm 25-30^{\circ} \mathrm{C}$, sangat lembab. Angin sedikit bertiup dari utara-barat dengan kecepata 4-7 Km/jam (Badan Pusat Statistika Kabupaten Nganjuk, 2016).

Peternak di wilayah Kecamatan Prambon mempunyai manajemen yang berbeda-beda, salah satunya yaitu kandang. Peternak menggunakan sistem lantai kandang yang langsung bersentuhan dengan tanah tanpa alas, sehingga kotoran kambing sulit untuk dibuang seluruhnya dan sulit untuk menjaga kebersihan, selain itu juga sanitasi kurang baik. Manajemen pemeliharaan ternak terutama sanitasi kandang dan kebersihan kandang yang kurang baik merupakan salah satu faktor yang mempengaruhi persentase penyakit cacingan (Raza dkk., 2012). 
Kambing di Indonesia banyak di infeksi oleh Haemonchus spp., Trichostrongylus spp., Cooperia spp., Oesophagostomum spp., dan Bunostomum spp (Beriajaya dan Coopeman 1996). Kerugian-kerugian akibat penyakit cacing saluran pencernaan, antara lain penurunan berat badan, penurunan kualitas daging, kulit, jerohan, penurunan produktivitas ternak, penurunan produksi susu pada ternak dan bahaya penularan pada manusia atau zoonosis (Gasbarre dkk., 2001). Oleh karena itu diperlukan suatu tindakan pencegahan dan pemberantasan sebagai usaha pengendalian penyakit cacing saluran pencernaan untuk menghindari kerugian yang lebih besar (Mustika dan Riza, 2004).

Berdasarkan latar belakang diatas maka perlu dilakukan penelitian tentang penyebaran cacing pada feses kambing di Kecamatan Prambon Kabupaten Nganjuk, dengan mengetahui jenis cacing yang menginfeksi maka segera dapat dilakukan pengobatan dengan jenis antihelmint yang tepat, sehingga pengobatannya menjadi lebih efektif. Data penyebaran helminthiasis yang diperoleh diharapkan bisa dimanfaatkan dalam usaha pemberantasan penyakit cacing dalam rangka pengembangan peternakan kambing dan mengurangi kerugian yang ditimbulkan.

\section{Materi dan Metode Prosedur penelitian}

Penelitian ini dilakukan pada bulan Agustus 2018 - Januari 2019. Sampel yang digunakan dalam penelitian ini adalah sampel feses kambing yang diambil pada bulan Agustus 2018 sebanyak 30 sampel feses segar, dan diambil pada bulan Desember 2018 - Januari 2019 sebanyak 78 sampel feses segar. Sampel berupa feses segar diambil kurang lebih 10 gram kemudian dimasukan kedalam kantong plastik dan diberi formalin $10 \%$ sebagai pengawetnya. Pada setiap kantong plastik diberi label atau penanda nomor sampel, lalu disesuaikan dengan pendataan sampel. Pemeriksaan sampel dilakukan dengan metode sederhana (natif), metode sedimentasi sederhana (simple sedimentation method) dan metode apung. Hasil pemeriksaan dinyatakan positif bila dalam salah satu metode tersebut ditemukan telur cacing. Identitifikasi telur cacing saluran pencernaan kambing dilakukan dengan merujuk pada buku panduan Soulsby (1986).

\section{Analisis data}

Analisis kejadian penyebaran helminthiasis pada saluran pencernaan kambing di Kecamatan Prambon Kabupaten Nganjuk dilakukan dengan analisis data yaitu analisis multi korespondensi.

\section{Hasil Penelitian}

Hasil pemeriksaan didapatkan jenis telur cacing kelas Nematoda dan Cestoda. Jenis telur cacing yang berasal dari kelas Nematoda antara lain Oesophagostomum spp., Bunostomum spp., Haemonchus spp., Trichostrongylus spp., Strongyloides spp., Chabertia spp., dan Trichuris spp., dan dari kelas Cestoda yaitu telur cacing Moniezia benedini.

Pada hasil penelitian didapatkan telur cacing yang terdiri dari 8 jenis yang berasal dari kelas Nematoda. Disajikan pada gambar berikut

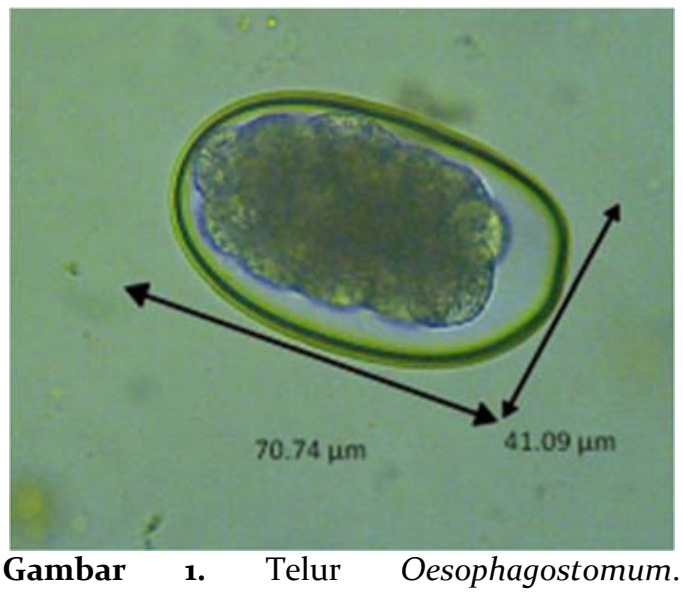

(Perbesaran 400x).

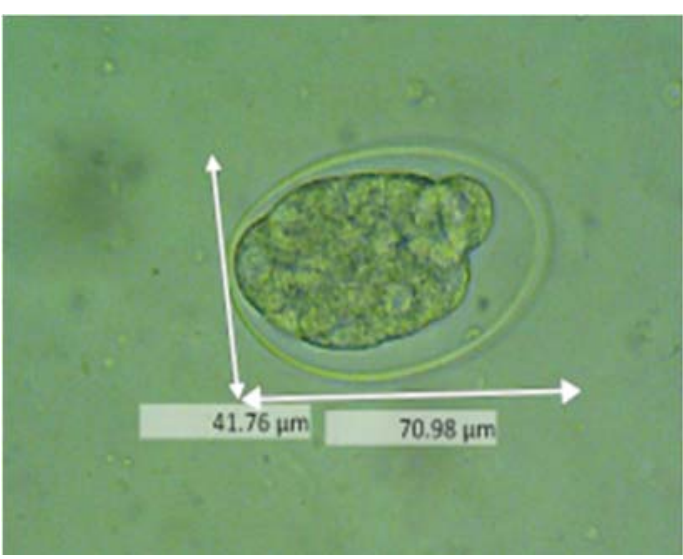

Gambar 2. Telur Haemonchus. (Perbesaran 400x). 


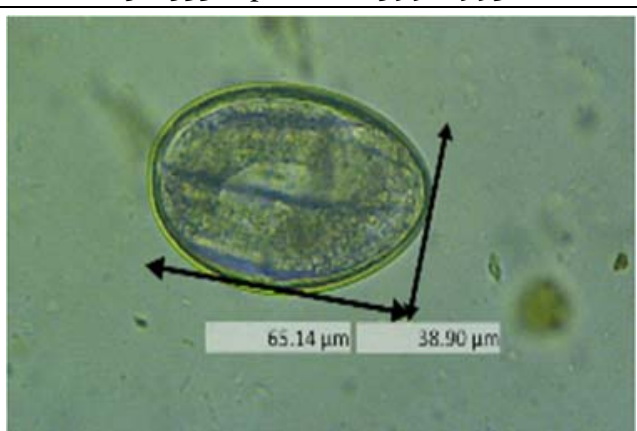

Gambar 3. Telur Strongyloides. (Perbesaran 400x).

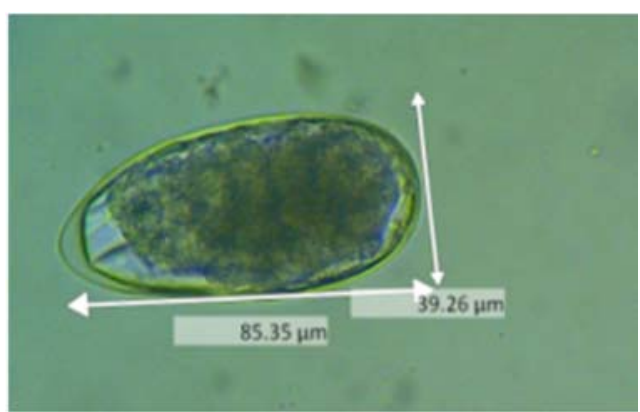

Gambar 4. Telur Trichostrongylus. (Perbesaran 400x).

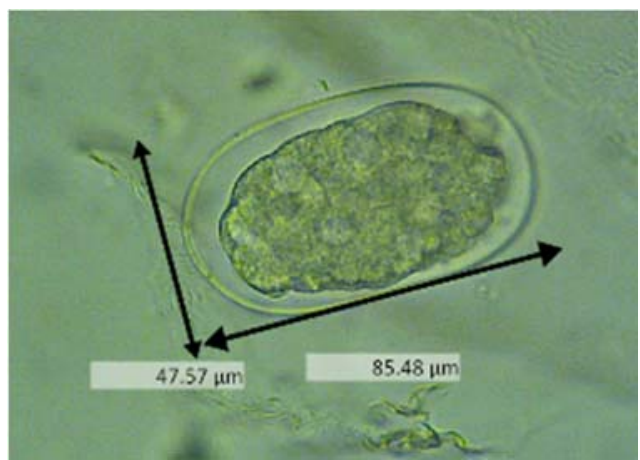

Gambar 5. Telur Bunostomum. (Perbesaran 400x).

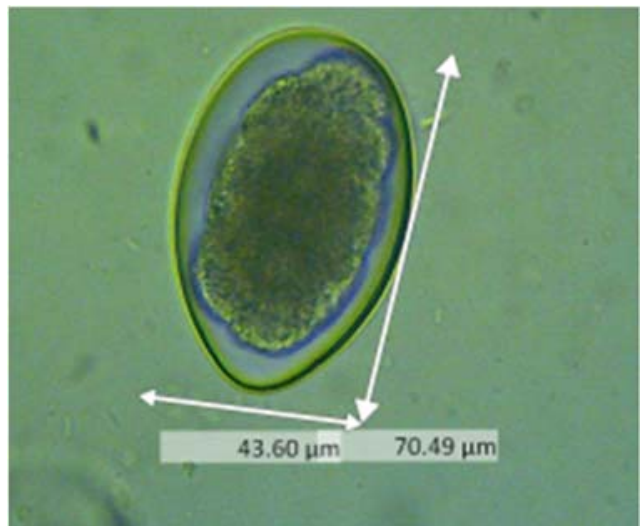

Gambar 6. Telur Chabertia ovina. (Perbesaran 400x).

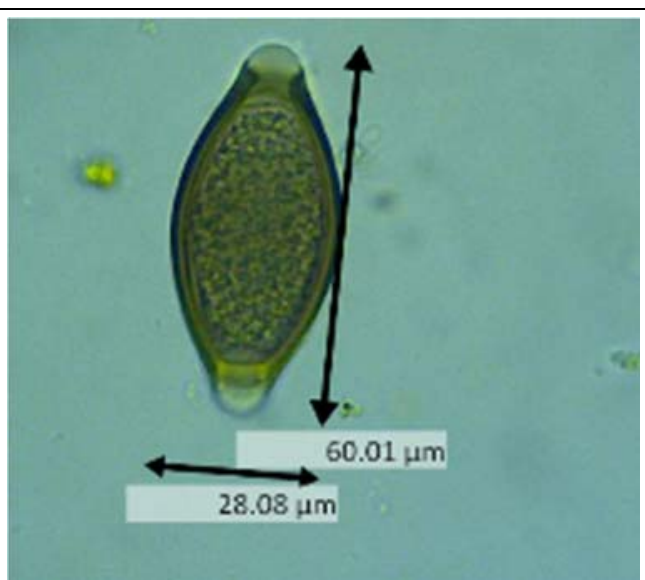

Gambar 7. Telur Trichuris. (Perbesaran 400x).

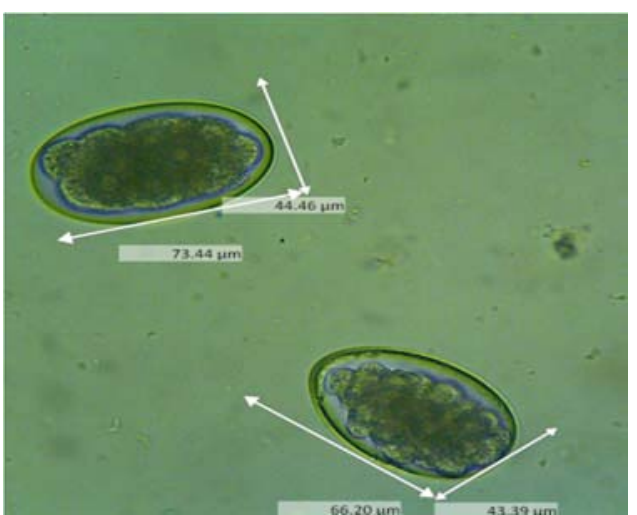

Gambar 8. Telur Haemonchus (Gambar A) dan Telur Oesophagostomum (Gambar B). (Perbesaran 400x).

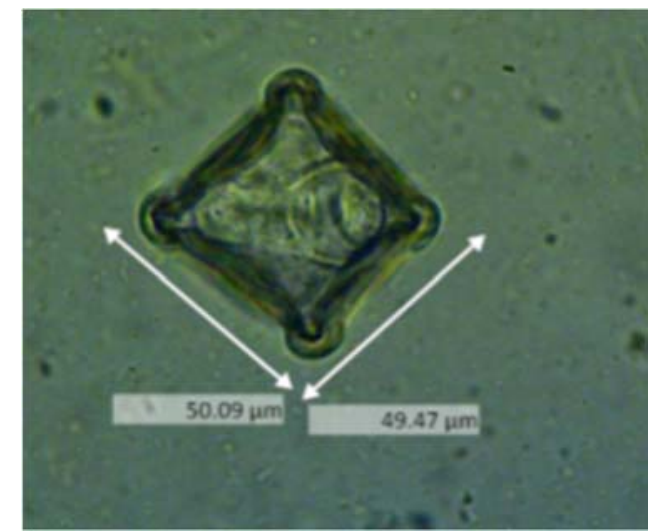

Gambar 9. Telur Moniezia benedeni. (Perbesaran 400x).

Sebaran dan identifikasi telur cacing saluran pencernaan kambing di Kecamatan Prambon pada Desa Sono dan Kurung yang diambil pada musim kemarau dan Desa Banyurib, Desa Bontoro dan Desa Waung pada musim penghujan dapat ditampilkan hasil seperti Gambar 10. 


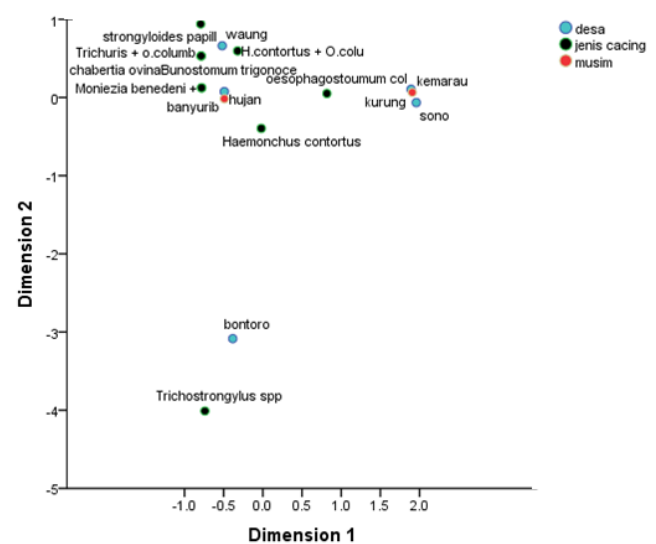

Gambar 10. Sebaran jenis telur cacing saluran pencernaan kambing di Kecamatan Prambon.

Pada gambar diatas dapat dilihat bahwa pada musim kemarau di Desa Kurung dapat telur cacing Haemonchus spp. dan Oesophagostomum spp., sedangkan pada Desa Sono Haemonchus spp. dan Oesophagostomum spp. namun dengan jumlah yang lebih sedikit daripada Desa Kurung.

Pada musim penghujan di Desa Bontoro cenderung lebih banyak ditemukan telur cacing Trichostrongylus spp., telur cacing Haemonchus contortus dapat ditemukan di Desa Bontoro namun sangat sedikit. Desa Banyurib pada musim penghujan dapat ditemukan jenis telur cacing seperti $M$. benedeni dan Oesophagostomum spp., Haemonchus spp. Oesophagostomum spp., Trichuris spp. dan Oesophagostomum spp., Chabertia ovina, Bunostomum spp., Strongyloides spp dan Haemonchus spp. Oesophagostomum spp dan Haemonchus spp. Pada Desa Waung terdapat infeksi.

telur cacing Strongyloides spp dan Haemonchus contortus, infeksi telur cacing Haemonchus contortus dan Oesophagostomum spp., infeksi campuran telur cacing Trichuris dan Oesophagostomum, infeksi tunggal Haemonchus contortus, Oesophagostomum spp , dan Chabertia spp. Sebaran jenis telur cacing saluran pencernaan kambing di Kecamatan Prambon dapat dilihat pada Tabel 1.
Infeksi tunggal ditemukan telur cacing Haemonchus spp., sebanyak 8 sampel positif pada musim kemarau dan sebanyak 16 sampel positif pada musim penghujan, telur Oesophagostomum spp sebanyak 4 sampel positif pada musim kemarau dan sebanyak 12 sampel positif pada musim penghujan, telur Chabertia spp sebanyak 4 sampel sebanyak pada musim penghujan dan telur Bunostomum spp sebanyak 1 sampel sebanyak pada musim penghujan.

Kejadian infeksi campuran ditemukan telur cacing Strongyloides spp. dan Haemonchus spp. sebanyak 6 sampel positif pada musim hujan dan tidak ditemukan pada musim kemarau, infeksi campuran antara telur cacing Trichostrongylus spp. dan Haemonchus spp. pada musim hujan 2 sampel positif dan tidak ditemukan pada musim kemarau, infeksi campuran antara telur cacing Oesophagostomum spp. dan Haemonchus spp. sebanyak 1 sampel positif pada musim kemarau dan sebanyak 7 sampel positif pada musim penghujan, infeksi campuran pada musim penghujan telur cacing telur cacing Trichuris spp. dan Oesophagostomum spp sebanyak 4 sampel positif dan terakhir campuran infeksi telur cacing Moniezia benedeni dan Oesophagostomum spp. sebanyak 1 sampel positif.

Hasil penelitian yang dilakukan pada bulan Agustus 2018-Januari 2019 terhadap 108 sampel feses kambing di Kecamatan Prambon, terdapat 66 sampel positif dan 42 sampel negatif. Pada musim hujan dari 78 sampel terdapat 53 sampel yang positif dan 25 sampel yang negatif, sedangkan pada musim kemarau dari 30 sampel terdapat 13 sampel positif dan 17 sampel negative

Hasil pemeriksaan juga didapatkan bahwa Desa Banyurib Kecamatan Prambon adalah desa paling tinggi tingkat infeksi telur cacingnya yaitu sebesar 35 sampel, kemudian disusul Desa Waung yaitu 14 sampel positif, lalu disusul dengan Desa Kurung sebesar 10 sampel, setelah itu Desa Bontoro dengan 4 sampel positif dan terakhir Desa Sono dengan 3 sampel positif dari 66 sampel positif. 
Tabel 1. Sebaran jenis telur cacing saluran pencernaan kambing di wilayah Kecamatan Prambon pada musim hujan dan kemarau

\begin{tabular}{|c|c|c|c|c|c|}
\hline \multirow{2}{*}{ Jenis Cacing } & \multicolumn{2}{|c|}{ Kemarau } & \multicolumn{3}{|c|}{ Hujan } \\
\hline & Sono & Kurung & Banyurib & Bontoro & Waung \\
\hline \multicolumn{6}{|l|}{ Infeksi Tunggal : } \\
\hline Haemonchus & 2 & 6 & 10 & 2 & 4 \\
\hline Oesophagostomum & 1 & 3 & 8 & 1 & 3 \\
\hline Chabertia & o & o & 3 & o & 1 \\
\hline Bunostomum & o & o & 1 & o & o \\
\hline \multicolumn{6}{|l|}{ Infeksi Campuran : } \\
\hline S. papillosus + Haemonchus & 0 & 0 & 3 & 0 & 3 \\
\hline \multirow{2}{*}{$\begin{array}{l}\text { Trichostrongylus + Haemonchus } \\
\text { Haemonchus + Oesophagostomum }\end{array}$} & o & o & 1 & 1 & o \\
\hline & o & 1 & 5 & o & 2 \\
\hline \multirow{2}{*}{$\begin{array}{l}\text { M.benedeni + Oesophagostomum } \\
\text { Trichuris + Oesophagostomum }\end{array}$} & o & o & 1 & o & o \\
\hline & $\mathrm{O}$ & $\mathrm{o}$ & 3 & $\mathrm{O}$ & 1 \\
\hline \multirow{2}{*}{ Jumlah } & 3 & 10 & 35 & 4 & 14 \\
\hline & \multicolumn{2}{|c|}{13} & & 53 & \\
\hline
\end{tabular}

\section{Pembahasan}

Tingginya persentase yang diperoleh saat musim penghujan dapat disebabkan berbagai macam faktor, diantaranya faktor lingkungan dan pemeliharaan, faktor pakan dan faktor musim. Sebaran telur cacing saluran pencernaan kambing di Kecamatan Prambon pada musim hujan yaitu dua kali dari musim kemarau, hal ini disebabkan karena pada musim hujan sangat baik untuk perkembangan telur dan larva cacing sehingga kejadian penyakit cacing lebih banyak ditemukan pada musim hujan daripada musim kemarau (Koesdarto dkk., 2007 ${ }^{\mathrm{b}}$ ). Sampel yang positif sebagian besar berasal dari hewan yang terserang penyakit diare.

Diare dapat disebabkan oleh pakan yang berjamur, hijauan yang terlalu muda dan mikroorganisme. Penyebab penyakit diare pada kambing secara garis besar dapat digolongkan menjadi dua bentuk, yaitu noninfeksi (pakan yang terlalu muda, daun-daunan dengan kadar protein yang tinggi, dan kualitas pakan yang rendah) serta agen infeksi (bakteri, virus dan protozoa) (Bahri dkk., 2004). Lingkungan dan pemeliharaan dengan sanitasi yang buruk dapat menyebabkan penyakit diare. Keadaan sanitasi yang buruk dapat disebabkan oleh tercemarnya lingkungan karena limbah ternak (Lidya dan Muliani, 2010). Berdasarkan hasil observasi, mayoritas masyarakat peternak kambing di Kecamatan Prambon terutama desa Banyurib memelihara ternak kambingnya langsung bersentuhan dengan tanah, sehingga kotoran ternak dan pakan tercampur menjadi satu.

Hasil pemeriksaan ditemukan tujuh jenis telur cacing yang sesuai dengan ciri-ciri telur cacing yang berasal dari kelas Nematoda dan satu jenis dari kelas Cestoda. Jenis telur cacing yang berhasil diidentifikasi adalah Oesophagostomum spp., Bunostomum spp., Haemonchus spp., Trichostrongylus spp., Strongyloides spp., Chabertia spp., dan Trichuris spp., dan dari kelas Cestoda yaitu telur cacing Moniezia benedini.

Telur Oesophagostomum spp. berukuran 70,74 x 41,09 $\mu \mathrm{m}$ dan berbentuk oval. Telur Bunostomum spp. yang ditemukan berukuran $85,48 \times 47,57 \mu \mathrm{m}$, telur ini lebih besar daripada telur Oesophagostomum spp. dan tampak tumpul. Telur Haemonchus spp. berukuran 70,74 x 41,76 $\mu \mathrm{m}$ dan berbentuk tumpul. Telur Trichostrongylus spp. yang ditemukan berukuran $85,35 \times 39,26 \mu \mathrm{m}$ dengan salah satu ujungnya lancip. Telur Strongyloides spp yang ditemukan berukuran 65,14 x 38,90 $\mu \mathrm{m}$ dimana didalam telur seperti ada bentukan larvanya. Telur Chabertia spp. yang ditemukan berukuran 70,49 x 43,60 $\mu \mathrm{m}$ dan berbentuk oval. Telur Trichuris spp. yang ditemukan berukuran 6o,00 x 28,00 $\mu \mathrm{m}$ dan berbentuk seperti buah lemon. Telur Moniezia benedini yang ditemukan berukuran 49,47 x 30,00 $\mu \mathrm{m}$ dan berrbentuk segiempat.

Telur Oesophagostomum spp. mempunyai satu lapisan atau selaput tipis. Bentuk permukaan elips. Telur yang dikeluarkan sudah mengandung 8-16 sel dan berukuran 73-89 x 34$45 \mu \mathrm{m}$. Telur Bunostomum spp. mempunyai ukuran 79-97 x 47-50 $\mu \mathrm{m}$, bentuk bulat lonjong dengan ujung tumpul dan berisi embrio. Telur Haemonchus spp. berukuran 70-85 x 31-48 $\mu \mathrm{m}$ keluar bersama feses inangnya dengan mengandung 16-32 sel embrio. Telur Trichostrongylus spp. berukuran 79-101 x 39-47 $\mu \mathrm{m}$, telur ini berbentuk oval dan bersegmen pada waktu 
dikeluarkan bersama feses. Telur Strongyloides spp berukuran 40-70 x 20-25 $\mu \mathrm{m}$, cacing ini tidak berwarna dan semi transparan. Telur Chabertia spp berukuran 70-100 x 43-48 $\mu \mathrm{m}$. Telur Trichuris spp berukuran 70-80 x 30-42 $\mu \mathrm{m}$, telur ini berwarna cokelat dan berbentuk seperti tong dengan kedua ujung mempunyai tutup atau sumbat transparan. Telur Moniezia benedini berbentuk segiempat dan mengandung pyriform apparatus serta mempunyai ukuran 56-57 $\mu \mathrm{m}$ (Koesdarto dkk., 2007 ${ }^{\mathrm{b}}$ ).

Telur cacing yang paling banyak ditemukan pada pemeriksaan feses kambing di Kecamatan Prambon Kabupaten Nganjuk berasal dari kelas Nematoda, hal ini dapat disebabkan karena siklus hidup cacing Nematoda pada umumnya cepat, terutama pada suhu yang sesuai dan tidak memerlukan induk semang perantara (Subekti dkk., 2007). Nematoda dapat tumbuh dengan optimum pada curah hujan diatas $55 \mathrm{~mm}$ dengan suhu maksimum rata-rata diatas $18^{\circ} \mathrm{C}$ (Levine, 1994). Cacing ini berkembang dengan baik pada musim hujan dibandingkan musim kemarau (Chiejina dan Fakae, 1984).

Haemonchus merupakan infeksi telur cacing terbesar sebanyak 8 sampel positif pada musim kemarau dan 16 sampel positif pada musim penghujan. Haemonchus spp tersebar luas di daerah tropis dan Kabupaten Nganjuk termasuk daerah yang beriklim tropis. Pada peternakan kambing dan domba terutama di musim penghujan, penyebaran Haemonchus dapat terjadi cepat dikarenakan fluktuasi jumlah telur Haemonchus pada kotoran cenderung dipengaruhi fluktuasi musim, yaitu dengan titik tertinggi pada musim hujan dan titik terendah pada musim kemarau (Soulsby, 1986).

Infeksi terbesar selanjutnya yaitu Oesophagustomum spp., sebanyak 4 sampel positif pada musim kemarau dan sebanyak 12 sampel positif pada musim penghujan hal ini disebabkan karena cacing Oesophagustomum spp banyak terdapat di negara-negara Asia seperti Indonesia yang beriklim tropis dan prevalensinya akan tinggi pada musim penghujan (Koesdarto dkk., 2007 ${ }^{\mathrm{a}}$.

Infeksi dari kelas Nematoda yang paling sedikit adalah infeksi dari Bunostomum spp., yaitu 1 sampel positif pada musim penghujan. Cuaca mempunyai peranan penting dalam penularan cacing Nematoda, menurut Supan Kusumamihardja (1993) dipagi hari larva Bunostomum spp yang terdapat di pucuk-pucuk rumput lebih banyak daripada disiang hari dan sore hari jumlahnya naik lagi, tetapi tidak mencapai jumlah pada pagi hari. Kondisi iklim terutama curah hujan mempengaruhi derajat infeksi cacing (Soulsby, 1986). Indonesia merupakan daerah tropis, menurut Supan Kusumamihardja (1993) menyatakan bahwa infeksi di musim penghujan lebih tinggi daripada musim kemarau. Kelas Nematoda yang berpotensi sebagai zoonosis adalah Strongyloides spp., Oesophagostomum spp., Haemonchus spp., Trichuris spp., dan Trichostrongylus spp.

Kelas Cestoda didapatkan infeksi cacing Moniezia benedini. Kambing, domba dan sapi akan terinfeksi bila memakan mites yang mengandung sistisertokoid yang infeksi, biasanya bersama rumput. Suhu dan kondisi lingkungan sangat mempengaruhi proses perkembangan telur misalnya pada suhu $6^{\circ} \mathrm{C}$ perlu waku 7 bulan untuk mencapai bentuk sistiserkoid, sedangkan pada suhu $26^{\circ}-28^{\circ} \mathrm{C}$ perlu waktu 3-4 bulan (Koesdarto dkk., 2007 ${ }^{\mathrm{b}}$ ).

Kejadian infeksi campuran pada musim kemarau ditemukan telur cacing Oesophagostomum spp dan Haemonchu contortus sebanyak 1 sampel positif dan sebanyak 7 sampel positif pada musim penghujan, infeksi campuran pada musim penghujan telur cacing Trichostrongylus spp dan Haemonchus contortus sebanyak 2 sampel positif, telur cacing Strongyloides papillosus dan Haemonchus contortus sebanyak 6 sampel positif, telur cacing Trichuris dan Oesophagostomum sebanyak 4 sampel positif dan terakhir campuran infeksi telur cacing Moniezia benedeni dan Oesophagostomum sebanyak 1 sampel positif. Menurut Levine (1994) infeksi campuran atau tunggal sering terjadi pada kambing, sehingga sulit untuk mengetahui pengaruh khusus yang ditimbulkan. Infeksi yang terjadi biasanya dilakukan oleh bermacam-macam jenis cacing yang terjadi baik pada abomasums, usus, dan organ lain sehingga pengaruhnya berupa kombinasi atau campuran dari parasit yang ada.

Berdasarkan penelitian yang telah dilakukan menunjukkan bahwa kondisi cuaca sangat berpengaruh dalam perkembangan telur cacing yang menginfeksi saluran pencernaan kambing, hal ini disebabkan karena pada musim penghujan peternak lebih sering memberikan pakan rumput hijau dan muda tanpa proses pelayuan. Hijaun segar dan muda inilah yang menjadi salah satu faktor penyebab tingginya infestasi cacing saluran pencernaan pada ternak kambing akibat pencemaran larva pada hijaun (Bahrie dkk., 2004). Pengambilan sampel untuk 
penelitian ini dilakukan pada bulan Desember 2018-Januari 2019 yang termasuk pada musim penghujan. Pada musim penghujan, tanah kandang dalam kondisi yang lembab dan becek, oleh karena itu wajar bila ditemukan infeksi cacing saluran pencernaan pada kambing di Kecamatan Prambon Kabupaten Nganjuk. Daerah yang lembab merupakan kondisi yang cocok untuk pertumbuhan berbagai jenis cacing, sehingga sangat memungkinkan berbagai jenis cacing untuk melakjutkan siklus hidupnya (Purwantan dkk., 2006).

\section{Kesimpulan}

Berdasarkan data yang diperoleh melalui penelitian mengenai Helminthiasis pada saluran pencernaan kambing di Kecamatan Prambon Kabupaten Nganjuk dapat disimpulkan sebagai berikut : 1) Ditemukan delapan jenis cacing yang menginfeksi saluran pencernaan kambing di Kecamatan Prambon, tujuh dari kelas Nematoda yaitu Oesophagostomum spp., Bunostomum spp., Haemonchus spp., Trichostrongylus spp., Strongyloides spp., Chabertia spp., dan Trichuris spp., dan dari kelas Cestoda yaitu telur cacing Moniezia benedini. 2) Jenis telu cacing yang sering menginfeksi kambing dikecamatan Prambon adalah telur cacing Haemonchus spp.

\section{Saran}

Berdasarkan penelitian tersebut disarankan Manajemen pemeliharaan terutama sanitasi dan sistem pemberian pakan disarankan untuk ditingkatkan khususnya pada musim hujan, sebab kandang pemeliharaan dapat menjadi sumber penyakit bila manajemennya kurang baik dan Program pemberian obat cacing dilaksanakan secara berkala dan berkesinambungan sebagai upaya pencegahan kasus infeksi cacing saluran pencernaan.

\section{Daftar Pustaka}

Badan Pusat Statistika Kabupaten Nganjuk. 2016. Kabupaten Nganjuk Dalam Angka. Dinas Kabupaten Nganjuk.

Bahri, Sjamsul dkk. 2004. Manajemen Kesehatan dalam Usaha Ternak Kambing. Prosiding Lokakarya Nasional Kambing Potong 2004. Bogor: Puslitbangnak.

Beriajaya dan P. Stevenson. 1985. The effect of antihelmintic treatment on the weight gain of village sheep in West Java. Proc. of the $3^{\text {nd }}$ AAAP Animal Science Congress, Seoul, South Korea.

Beriajaya dan D.B. Coopeman. 1996. Seasonal differences in the effect of nematode parasitism on weight gain of sheep and goats in Cigudeg, West Java. Jurnal Ilmu Ternak dan Veteriner 2 (1): 66-72.

Chiejina, S.N dan B.B Fakae. 1984. Development and survival of infective larvae of gastrointerstinal nematode parasites of cattle on pasture in estern Nigeria. Res Vet Scie. 37: 148-153.

Dinas Peternakan Jawa Timur 2012. Data Jumlah Populasi Ternak 2012. Jawa Timur.

Gasbarre, L.C., E.A. Leighton, W.L. Stout. 2001. Gastrointerstinal Nematodes of Cattle in Thenortheastern US: Result of a Producer Survey. Veterinary Parasitology. 101. 29-44.

Ilham, F. 2014. "Keragaman Fenotipe Kambing Lokal Kabupaten Bone Bolango". Dalam Prosiding Seminar Nasional dan Workshop Optimalisasi Sumber Daya Lokal pada Peternakan Rakyat Berbasis Teknologi-1 di UNHAS, Makassar, 9-10 Oktober 2014. Hlm. 41-50.

Koesdarto, S., S. Subekti, S. Mumpuni, H. Puspitawati dan Kusnoto. 2007 . Buku Ajar Ilmu Penyakit Trematoda dan Cestoda Veteriner. Departemen Pendidikan Nasional Fakultas Kedokteran Hewan Universitas Airlangga. Surabaya. 22-24:33 : 44-45.

Kusumamihardja, S. 1993. Parasit dan Parasitosis pada Hewan Ternak dan Hewan Piaraan di Indonesia. Pusat Antar Universitas Bioteknologi. Institut Pertaniaan Bogor. 1316.

Lidya, Maryani dan Muliani Rizki. 2010. Epidemiologi Kesehatan: Pendekatan Penelitian. Yogyakarta: Graha Ilmu. 76-77.

Levine, N.D. 1994. Parasitologi Veteriner. Diterjemahkan oleh Ashadi G. Gadjah Mada University Press. Yogyakarta. 123-125.

Mustika, Ika dan Z. A. Riza. (2004). Peluang Pemanfaatan Jamur Nematofagus untuk Mengendalikan Nematoda Parasit pada Tanaman dan Ternak. Jurnal Litbang Pertanian, 23(4): 115. V. 
Purwantan, P., Ismaya N.R., Burhan. 2006. Penyakit Cacing Hati (Fasciolasis) Pada Sapi Bali di Perusahaan Daerah Rumah Potong Hewan (RPH) Kota Makassar. Jurnal Agrisistem Vol 5 (1): 10-21.

Raza, M.A., H.A. Bachaya, M.S. Akhtar, H.M. Arshad, S. Murtaza, M.M. Ayaz, M. Najeem and A. Basit. 2012. Point Prevalence of Gatrointerstinal Helminthiasis in Buffaloes (Bubalus Bubalis) at The Vicinity of Jatoi, Punjab, Pakistan, Sci. int. (Lahore), 24(4): 465-469.

Soulsby, E.J.L. 1986. Helminth, Arthropods and Protozoa of Domesticated Animal 7th Ed. The English Languange Book Socienty and Baillire Tindal. London. 143-256.
Subekti, S., S. Mumpuni, dan Kusnoto. 2007. Ilmu Penyakit Nematoda Veteriner. Departemen Pendidikan dan Kebudayaan. Fakultas Kedokteran Hewan. Universitas Airlangga. Surabaya. 89-95.

Yulianto, I. (2007). Hubungan Higiene Sanitasi dengan Kejadian Penyakit Cacingan pada Siswa Sekolah Dasar Negeri Rowosari o1 Kecamatan Tembalang Kota Semarang Tahun Ajaran 2006/2007. Skripsi. Semarang: Universitas negeri Semarang. 66-73.

Zeryehun, T. 2012. Helminthosis of sheep and goats in and around Haramaya, Southeastern Ethiopia. J. Vet. Med. Anim. Health 4: 48-55 